\title{
Risk Factors of Deep Vein Thrombosis
}

\author{
Mustafa Sirlak, Mustafa Bahadir Inan, \\ Demir Cetintas and Evren Ozcinar \\ Ankara University School of Medicine, Department of Cardiovascular Surgery, \\ Ankara, \\ Turkey
}

\section{Introduction}

Deep vein thrombosis is a clinical challenge for doctors of all disciplines. It can complicate the course of a disease but might also be encountered in the absence of precipitating disorders. Thrombosis can take place in any section of the venous system, but arises most frequently in the deep veins of the leg. Long-term morbidity due to post-thrombotic syndrome is common and can be substantial. The major concern, however, is embolisation of the thrombus to the lung, which can be fatal. Deep vein thrombosis is highly prevalent and poses a burden on health economy. The disorder and its sequelae are also among the best examples of preventable diseases. Relevant data for the frequency of deep vein thrombosis derive from large community-based studies because they mainly reflect symptomatic rather than asymptomatic disease. In a systematic review, the incidence of first deep vein thrombosis in the general population was 0.5 per 1000 person-years. ${ }^{1}$ The disorder is rare in children younger than 15 years, ${ }^{2,3}$ but its frequency increases with age, with incidence per 1000 person-years of 1.8 at age 65-69 years and $3 \cdot 1$ at age 85-89 years.4 Two-thirds of first-time episodes of deep vein thrombosis are caused by risk factors, including surgery, cancer, immobilisation, or admission for other reasons.5,6 Risk for first deep vein thrombosis seems to be slightly higher in men than in women. ${ }^{6,9}$ In a populationbased cohort study, the age-adjusted incidence of first venous thromboembolism was 13 per 1000 person-years in men and $1 \cdot 1$ per 1000 person-years in women. ${ }^{2}$ It is noteworthy that the risk for recurrence of this disorder is higher in men than in women.6,10

\begin{tabular}{l} 
Conditions associated with increased risk for deep vein thrombosis \\
\hline Advancing age \\
\hline Obesity \\
\hline Previous venous thromboembolism \\
\hline Surgery \\
\hline Trauma \\
\hline Active cancer \\
\hline $\begin{array}{l}\text { Acute medical illnesses - eg, acute myocardial infarction, heart failure, respiratory failure, } \\
\text { infection }\end{array}$ \\
\hline Inflammatory bowel disease \\
\hline
\end{tabular}




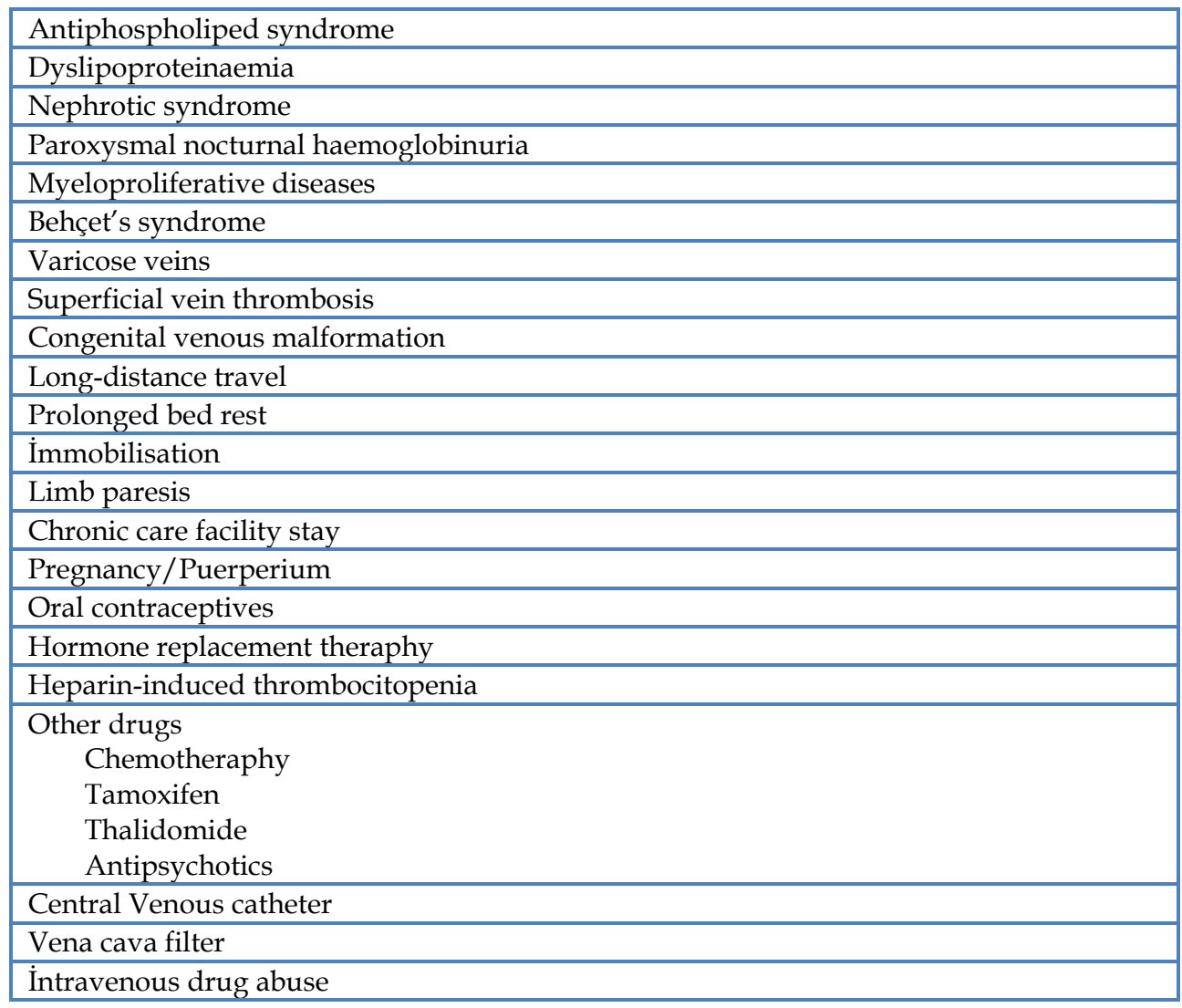

Rudolph Virchow is recognized as the first person to link the development of VTE to the presence of at least 1 of 3 conditions: venous stasis, vascular injury, and/or hypercoagulability. 11 Each of these factors can alter the delicate hemostatic balance toward hypercoagulability and development of thrombosis. Several aspects of surgery can be linked to Virchow's triad. Coleridge-Smith et al12 reported in 1990 that venous stasis occurs during general surgery, with veins dilating $22 \%$ to $28 \%$ in patients undergoing general anesthesia and surgery and up to $57 \%$ in those who also received an infusion of $1 \mathrm{~L}$ of saline during surgery. The investigators suggested that it is this intraoperative venous distension that underlies the risk for DVT in patients undergoing surgery. They suggested that the venous distension is the result of loss of muscle tone that is caused by the muscle relaxants used during surgery. Muscle paralysis resulting from regional anesthesia also can lead to venous dilatation. These effects can be modified to some extent by the use of graduated compression stockings during surgery.13 In a study of 40 patients undergoing surgery of the abdomen or neck, the median vein diameter in the extremity studied was $2.6 \mathrm{~mm}$ at the beginning of surgery in both the control and intervention groups (control group, $\mathrm{n}=20$; median vein diameter, $2.6 \mathrm{~mm}$; interquartile range [IQR], 2.1-3.3 mm; stocking group, $\mathrm{n}=20$; median vein diameter, $2.6 \mathrm{~mm}$; IQR, 2.1-3.7 mm). This decreased to a median vein diameter of $1.6 \mathrm{~mm}$ (IQR, 1.3-2.8 mm) after application of a stocking, whereas vein diameter 
increased from 2.6 to $2.9 \mathrm{~mm}$ (IQR, 2.3- $4.0 \mathrm{~mm}$ ) in the control group.13 Comerota et al14 found that in patients undergoing total hip replacement surgery, handling of soft tissue (muscle) during surgery leads to venodilation, whereas bone manipulation leads to venoconstriction. The venous dilatation that occurs during surgery causes cracks in the endothelium, which provides a nidus for thrombosis as the blood coagulation system is activated. The researchers also showed that pharmacologic control of venodilation during surgery reduced postoperative DVT.14 Microscopic vessel wall damage, 15 such as that demonstrated in patients undergoing hip and knee replacement surgeries, also contributes to the development of VTE. 16,17 Tissue factor released from the blood vessel wall after injury drives thrombus formation, 18 which may help explain the increased risk of VTE in patients undergoing surgery. The third factor in Virchow's triad, hypercoagulability, is linked to a number of factors, including certain genetic traits. Deficiencies of antithrombin, protein C, or protein S, or mutations of factor V Leiden or factor II (prothrombin) G20210A genes lead to hypercoagulable states.11 Although these genetic factors account for only a small percentage of the total cases of VTE, more than half of all patients with juvenile or idiopathic VTE have been identified with an inherited thrombophilic condition.11. Given that VTE is the leading preventable cause of in-hospital deaths, 19 every patient should be screened before other lesser screens are performed (bedsores, risk of falls, nutritional evaluation, and so forth). Stated another way - every patient deserves a proper history and physical to uncover any possible factors that might increase their risk of a VTE.

\begin{tabular}{|l|c|c|c|c|}
\hline & \multicolumn{2}{|c|}{$\begin{array}{c}\text { Deep vein } \\
\text { thrombosis }\end{array}$} & \multicolumn{2}{c|}{$\begin{array}{c}\text { Pulmonary } \\
\text { embolism }\end{array}$} \\
\hline & Calf & Proximal & Clinical & Fatal \\
\hline $\begin{array}{l}\text { Low risk (minor surgery in patients < } 40 \text { years } \\
\text { with no additional risk factors) }\end{array}$ & $2 \%$ & $0-4 \%$ & $0-2 \%$ & $<0,01 \%$ \\
\hline $\begin{array}{l}\text { Moderate risk (minor surgery and additional } \\
\text { risk factor }\end{array}$ & $10-20 \%$ & $2-4 \%$ & $1-2 \%$ & $0,1-0,4 \%$ \\
\hline $\begin{array}{l}\text { High risk (surgery in patients > 60 years or age } \\
40-60 \text { years with additional risk factors (previous } \\
\text { venous thromboembolism, cancer, thrombophilia) }\end{array}$ & $20-40 \%$ & $4-8 \%$ & $2-4 \%$ & $0,4-1,0 \%$ \\
\hline $\begin{array}{l}\text { Highest risk (surgery in patients with multiple } \\
\text { risk factors [age > 40 years, cancer, previous } \\
\text { venous thromboembolism]: hip or knee } \\
\text { arthroplasty, hip fracture surgery; major trauma - } \\
\text { spinal cord surgery) }\end{array}$ & $40-80 \%$ & $10-20 \%$ & $4-10 \%$ & $0,2-5 \%$ \\
\hline Modified from reference 16 with permission of the American College of Chest Physicians. \\
\hline
\end{tabular}

Table 1. Risk of venous thromboembolism in surgical patients without prophylaxis

In 1992, the Thromboembolic Risk Factors (THRIFT) Consensus Group identified acquired risk factors for VTE.20 Sixteen years later, the most recent update of the American College of Chest Physicians (ACCP) guidelines for VTE prophylaxis reveals essentially the same risk factors for VTE as those identified by THRIFT, with the addition of a few new ones, including acute medical illness, and the removal of smoking as a separate risk factor (Table 
1). 19 The incidence of VTE increases dramatically in tandem with the number of risk factors identified in patients.11,21 Most hospitalized patients have at least one risk factor for VTE, and the most recent ACCP review of VTE estimated that approximately $40 \%$ have 3 or more risk factors.19 These include fracture (hip or leg), hip or knee replacement, major general surgery, major trauma, and spinal cord injury,11 as well as a history of VTE,11 thrombophilia, 11 inflammatory bowel disease, 22 postoperative infection, 19 and cancer.23 Bed rest for more than 72 hours,11,24 use of hormones,11 and impaired mobility 11 are additional risk factors. Many of these factors are not simple binary (ie, yes/no) risks. For example, age is a significant risk factor, with the risk approximately doubling with each decade beyond age 40.11,25 It is not sufficient to use a single age cut-off level to define high or low risk.11 Similarly, the incidence of VTE increases with length of surgery.26,27 In addition, Sugerman et al28 found higher rates of VTE in obese patients (mean body mass index, 61) who also had venous stasis syndrome; a simple cut-off level based on a definition of obesity would not capture this increased risk. In fact, Anderson and Spencer11 suggest that the association of risk of VTE and weight alone is a weak one. As noted earlier, hospitalized patients usually have at least 1 risk factor for VTE, and more than a third of hospitalized patients have 3 risk factors or more.19 Risk factor weighting can be used to calculate the risk for an individual patient, and the results may be used to determine several aspects of prophylaxis, such as the length of prophylaxis (including out-of-hospital prophylaxis), selection of prophylactic agent, timing of first dose, and the need for combined use of physical and pharmacologic methods.

Risk assessment typically has taken 1 of 2 approaches, group risk assessment or individual risk assessment. The group risk assessment approach assigns patients to one of a few broad risk categories, whereas individual risk assessment seeks to define risk more accurately by using individualized risk scores.19 The system recommended by the 2001 ACCP guidelines used a group risk assessment in which the type of surgery ("major" vs "minor"), age bracket, and presence of additional risk factors were used to assign patients to 1 of 4 risk groups29; however, this was based on older studies, arbitrary age cut-off levels, and inexact definitions. ${ }^{19}$ The ACCP has refined this recommendation with a newer one in which patients are assigned 1 of 3 VTE risk levels based on type of surgery, patient mobility, overall risk of bleeding, and moderate/high risk of VTE based on the presence of additional risk factors 19 As the investigators note, this group risk assessment approach ignores the substantial variability in patient-specific risk factors, but it does take into account what they view as the principal risk factor (surgery vs acute medical illness). This approach is most appropriate for patients who fit the criteria of the randomized clinical trials that were used to develop the model; the investigators include a disclaimer for patient groups that have not been included in clinical trials or for types of patients who have not been tested.19 However, the group risk assessment approach recommended by the ACCP may not be appropriate for all individual patients.30 Out-of-hospital prophylaxis is not addressed except for a few very high risk groups (major cancer surgery, total joint replacement).19 It may be more appropriate to use the individual risk assessment approach to identify and evaluate all possible risk factors to determine the true extent of risk for a patient.30 The ACCP guidelines, in fact, point out that "specific knowledge about each patient's risk factors for VTE" is an essential component of the decision-making process when prescribing thromboprophylaxis. 19 Also, if many risk factors are present and a planned procedure is 
based on a quality-of-life decision rather than a critical medical need, the patient may come to a different decision about whether to proceed.30 A common misconception among physicians is that individual risk assessment takes longer and is more cumbersome than group risk assessment. However, individual assessment can be accomplished with, for example, a simple assessment form that merely captures information from the history and physical examination of the patient.

Among all patients with PE in the PIOPED II trial $94 \%$ had 1 or more of the following assessed risk factors: bed rest within the last month of 3 days or more, travel within the last month of 4 hours or more, surgery within 3 months, malignancy, past history of DVT or PE, trauma of lower extremities or pelvis, central venous instrumentation within 3 months, stroke, paresis or paralysis, heart failure or chronic obstructive pulmonary disease (COPD).31 Immobilization of only 1 or 2 days may predispose to PE, and $65 \%$ of those who were immobilized were immobilized for 2 weeks or less. 32

\section{Obesity and height}

Investigations that reported an increased risk for VTE caused by obesity have been criticized because they failed to control for hospital confinement or other risk factors.33 High proportions of patients with VTE have been found to be obese,13,34 but the importance of the association is diminished because of the high proportion of obesity in the general population.35 Some investigations showed an increased risk ratio for DVT or PE in obese women,21,36,38 but data in men were less compelling. The Nurses' Health Study showed that the age-adjusted risk ratio for PE women with a body mass index (BMI, calculated as weight in kilograms divided by the square of height in meters) $29.0 \mathrm{~kg} / \mathrm{m} 2$ or higher was 3.2 compared with the leanest category of less than $21.0 \mathrm{~kg} / \mathrm{m} 2.36$ The Framingham Heart Study showed that metropolitan relative weight was significantly and independently associated with PE among women, but not men.39 However, the Study of Men Born in 1913 showed that men in the highest decile of waist circumference $(>100 \mathrm{~cm})$ had an adjusted relative risk for VTE of 3.92 compared with men with a waist circumference less than 100 $\mathrm{cm} .40$ Among 1272 outpatients (men and women), the odds ratio for DVT, comparing obese (BMI> $30 \mathrm{~kg} / \mathrm{m} 2$ ) with nonobese patients, was 2.39 .41 Others showed a similar odds ratio for DVT of 2.26 compared with nonobese patients.37 BMI correlated linearly with the development of PE in women.42 On the other hand, the Olmsted County, Minnesota casecontrol study found no evidence that current BMI was an independent risk factor for VTE in men or women.33,43 Others did not show obesity to be a risk for VTE in men.21,38 Analysis of the huge database of the National Hospital Discharge Survey44 showed compelling evidence that obesity is a risk factor for VTE.45 Among patients hospitalized in short-term hospitals throughout the United States, in whom obesity was coded among the discharge diagnoses but not defined, 91,000 of 12,015,000 (0.8\%) had PE.45 Among hospitalized patients who were not diagnosed with obesity, PE was diagnosed in 2,366,000 of 691,000,000 (0.3\%). DVT was diagnosed in 243,000 of 12,015,000 (2.0\%) of patients diagnosed with obesity, and in 5,524,000 of $691,000,000(0.8 \%)$ who were not diagnosed with obesity. The relative risk of PE, comparing obese patients with nonobese patients, was 2.18 and for DVT it was 2.50.45 The relative risks for PE and DVT were age dependent. Obesity had the greatest effect on patients less than 40 years of age, in whom the relative risk for PE in obese patients was 5.19 and the relative risk for DVT was 5.20.45 The higher relative risk of obesity in younger patients may have reflected that younger patients uncommonly have multiple 
confounding- associated risk factors, which make the risk of obesity inapparent. Previous investigators used several indices of obesity including a BMI greater than $35 \mathrm{~kg} / \mathrm{m} 2$ as well as BMI 30 to $35 \mathrm{~kg} / \mathrm{m} 2,46 \mathrm{BMI} 29 \mathrm{~kg} / \mathrm{m} 2$ or greater, 36 weight more than $20 \%$ of median recommended weight for height,13 and for men, waist circumference $100 \mathrm{~cm}$ or greater.40 It is likely that all patients diagnosed with obesity in the National Hospital Discharge Survey database were obese, irrespective of the criteria used. However, some obese patients may not have had a listed discharge diagnosis of obesity, and they would have been included in the nonobese group. This situation would have tended to reduce the relative risk of obesity in VTE. Various abnormalities of hemostasis have been described in obesity, in particular increased plasminogen activator inhibitor-1 (PAI-1).47,48 Other abnormalities of coagulation have been reported as well,48 including increased platelet activation,39 increased levels of plasma fibrinogen, factor VII, factor VIII, and von Willebrand factor.49 Fibrinogen, factor VIIc, and PAI-1 correlated with BMI.50 Regarding height, in the study of Swedish men, those taller than $179 \mathrm{~cm}\left(5^{\prime} 10^{\prime \prime}\right)$ had a 1.5 times higher risk of VTE than men shorter than 172 cm.51 The Physicians' Health Study of male physicians also showed that taller men had a significantly increased risk of VTE.52

\section{Air travel}

The possibility of VTE after travel is not unique to air travel.53,54 Prolonged periods in cramped quarters, irrespective of travel, can lead to PE. 55 The term economy class syndrome was introduced in 1988,56 but has since been replaced with flight-related DVT in recognition that all travelers are at risk, irrespective of the class of travel ${ }^{57}$ Rates of development of PE with air travel lasting 12 to 18 hours have been calculated as 2.6 $\mathrm{PE} /$ million travelers.58 With air travel of 8 hours or longer, $1.65 /$ million passengers had acute PE on arrival.59 With 6 to 8 hours of air travel the rate of acute PE on arrival was $0.25 /$ million and among those who traveled for 6 hours or less none developed acute PE on arrival.59 The trend showing increasing rates of PE with duration of travel is compelling, but the incidence of DVT was about 3000 times higher in a prospective investigation.60 In a prospective investigation of travelers who traveled for 10 hours or longer, 4 of $878(0.5 \%)$ developed PE and 5 of 878 (0.6\%) developed DVT.60

\section{Varicose veins}

Varicose veins were found by some to be an agedependent risk factor for VTE.43 Among patients aged 45 years the odds ratio for VTE was 4.2.43 In patients aged 60 years the odds ratio was 1.9 and at aged 75 years, varicose veins were not associated with an increased risk of VTE.43 However, others did not find varicose veins to be a risk factor for DVT61 or PE found at autopsy. 21

\section{Oral contraceptives}

Although the risk of VTE is higher among users of oral estrogen-containing contraceptives than nonusers, 62,63 the absolute risk is low.64 An absolute risk of VTE of less than 1/10,000 patients/y increased to only 3 to $4 / 10,000$ patients/y during the time oral contraceptives were used.64 The relative risk for VTE in women using oral contraceptives containing $50 \mathrm{mg}$ of estrogen, compared with users of oral contraceptives that contained less than $50 \mathrm{mg}$ was 1.5.65 The relative risk for VTE in women using oral contraceptives containing more than $50 \mathrm{mg}$ of 
estrogen, compared with users of oral contraceptives that contained less than $50 \mathrm{mg}$ was 1.7 .65 No difference in the risk of VTE was found with various levels of low doses of 20,30, 40, and $50 \mathrm{mg} / \mathrm{d} .66$ With doses of estrogen of $50 \mathrm{mg} / \mathrm{d}$, the rate of VTE was 7.0/ 10,000 contraceptive users/y and with more than $50 \mathrm{mg} / \mathrm{d}$, the rate of VTE was 10.0/10,000 oral contraceptive users/y.65 However, some found no appreciable difference in the relative risk of VTE in relation to low or higher estrogen doses.67 Reports of the risk of VTE in relation to the duration of use of oral contraceptives are inconsistent. Some showed relative risks increased as the duration of use of estrogen-containing oral contraceptives increased.68 The relative risks were 0.7 in women who used oral contraceptives for less than 1 year, 1.4 for those who used oral contraceptives for 1 to 4 years and 1.8 in those who used it for 5 years or longer.68 Others showed the opposite effect, with a decreasing relative risk with duration of use.66 The relative risk for DVT or PE was 5.1 with use for less than 1 year, 2.5 with use for 1 to 5 years, and 2.1 with use for longer than 5 years. 66 Some showed the risk to be unaffected by the duration of use.67 A synergistic effect of oral contraceptives with obesity has been shown.69,71 The odds ratio of DVT in obese women (BMI_30 kg/m2) who were users of oral contraceptives ranged from 5.2 to 7.8 compared with obese women who did not use oral contraceptives37,69,71 and among women with a BMI $35 \mathrm{~kg} / \mathrm{m} 2$ or higher, the odds ratio was 3.1 compared with similarly obese nonusers of oral contraceptives.71

\section{Tamoxifen}

Tamoxifen is a selective estrogen-receptor modulator used for treatment of breast cancer and for prevention of breast cancer in high-risk patients.72,74 Among women with breast cancer currently being treated with tamoxifen, compared with previous users or those who never used it, the odds ratio was 7.1.74 Others found a lower odds ratio of 2.7.43 The odds ratio for VTE in women at high risk of breast cancer who received tamoxifen to prevent breast cancer was 2.1.73 Others found a hazard ratio of 1.63 .72

\section{Hormonal replacement therapy}

There is a 2- to 3-fold increased risk of VTE with the use of hormone replacement therapy in postmenopausal women.75,76 Among postmenopausal women who had coronary artery disease and received estrogen plus progestin, the relative hazard of VTE was 2.7 compared with nonusers.77 Review showed that the risk of VTE is highest in the first year of hormone replacement therapy.78 The risk of VTE is increased for oral estrogen alone, oral estrogen combined with progestin, and probably for transdermal hormone replacement therapy.78

\section{Congenital hypercoagulable disorders}

\subsection{Antithrombin deficiency}

Antithrombin is a serine protease inhibitor of thrombin and also inhibits factors IXa, Xa, XIa, and XIIa. Thrombin is irreversibly bound by antithrombin and prevents thrombin's action on fi brinogen, on factors V, VIII, and XIII, and on platelets. ${ }^{79}$ This anticoagulant is synthesized in the liver and endothelial cells, and has a half-life of 2.8 days. ${ }^{80}$ Antithrombin deficiency has a prevalence of 1 : 5000 with more than 100 genetic mutations and an autosomal dominant inheritance pattern. ${ }^{81}$ Homozygotes typically die in utero whereas heterozygotes typically have an antithrombin level that is 40 to $70 \%$ of normal. 
Antithrombin deficiency is associated with lower extremity venous thrombosis as well as mesenteric venous thrombosis. The most common presentation in those with antithrombin deficiency is deep venous thrombosis with or without pulmonary embolism. ${ }^{82}$

\subsection{Protein $\mathrm{C}$ and protein S deficiency}

Protein $\mathrm{C}$ is a vitamin $\mathrm{K}$ dependent anticoagulant protein that, once activated by thrombin, will inactivate factors $\mathrm{Va}$ and VIIIa, thereby inhibiting the generation of thrombin. 83 Additionally, activated protein $\mathrm{C}$ stimulates the release of t-PA. It is produced in the liver and is the dominant endogenous anticoagulant with an eight-hour half-life. Protein $\mathrm{C}$ deficiency has a prevalence of 1 in 200-300 with more than 150 mutations and an autosomal dominant inheritance. 83,84

Protein $\mathrm{S}$ is also a vitamin $\mathrm{K}$ dependent anticoagulant protein that is a cofactor to activated protein $\mathrm{C}$. The actions of protein $\mathrm{S}$ are regulated by complement $\mathrm{C} 4 \mathrm{~b}$ binding protein and only the free form of protein $\mathrm{S}$ serves as an activated protein $\mathrm{C}$ cofactor. ${ }^{85}$ Additionally, protein $S$ appears to have independent anticoagulant function by directly inhibiting procoagulant enzyme complexes. ${ }^{84,86}$ The prevalence of protein $S$ defi ciency is about $1: 500$ with an autosomal dominant inheritance.

Clinically, protein C and S deficiencies are essentially identical. With homozygous protein C and $S$ defi ciencies, infants typically will succumb to purpura fulminans, a state of unrestricted clotting and fi brinolysis. In heterozygotes, venous thromboses may occur at an early age especially in the lower extremity. .7 Thrombosis may also occur in mesenteric, renal, and cerebral veins.

\subsection{Factor $\mathrm{V}$ Leiden mutation and activated protein $\mathrm{C}$ resistance}

Factor $\mathrm{V}$ is a glycoprotein synthesized in the liver. With Factor V Leiden, a point mutation occurs when arginine is substituted by glutamine at position 506 . This point mutation causes the activated Factor $\mathrm{V}$ to be resistant to inactivation by activated protein $\mathrm{C}$ thus causing a procoagulant state.

Clinically, patients may present with deep venous thrombosis in the lower extremities, or less commonly in the portal vein, cerebral vein, or superfi cial venous system.

\subsection{Prothrombin G20210 polymorphism}

Prothrombin (Factor II) is a zymogen synthesized in the liver and dependent on vitamin K. When prothrombin is activated, it forms thrombin (Factor IIa). A single mutation where adenine is substituted for guanine occurs at the 20210 position. The mechanism for increased thrombotic risk is not well understood, but individuals with this genetic variant have supranormal levels of prothrombin. The mutation is inherited as an autosomal dominant trait and is associated with both arterial and venous thrombosis.

Clinically, patients may present with deep venous thrombosis of the lower extremity, cerebral venous thrombosis, as well as arterial thrombosis. The risk of thrombosis increases in the presence of other genetic coagulation defects and with acquired risk factors. ${ }^{88,84}$ 


\subsection{Hyperhomocysteinemia}

Homocysteine is an amino acid formed during the metabolism of methionine and may be elevated secondary to inherited defects in two enzymes that are part of the conversion of homocysteine to cysteine. The two enzymes involved are N5,N10-methylene tetrahydrofolate reductase (MTHFR) or cystathionine beta-synthase. Hyperhomocysteinemia has been shown to increase the risk of atherosclerosis, atherothrombosis, and venous thrombosis. Elevated plasma homocysteine levels cause various dysfunctions of endothelial cells leading to a prothrombotic state.

Hypercoagulable syndromes include inherited and acquired thrombophilias. The former is discussed in detail in the article by Weitz in this issue. The latter includes the antiphospholipid syndrome, heparin-induced thrombocytopenia, acquired dysfibrinogenemia, myeloproliferative disorders, and malignancy. Myeloproliferative disorders and malignancy are described elsewhere in this article. Regarding the antiphospholipid syndrome, antiphospholipid antibodies are associated with both arterial and venous thrombosis.89 The most commonly detected subgroups of antiphospholipid antibodies are lupus anticoagulant antibodies, anticardiolipin antibodies and anti-b2glycoprotein I antibodies.90 DVT, the most common manifestation of the antiphospholipid syndrome, occurs in $29 \%$ to $55 \%$ of patients with the syndrome, and about half of these patients have pulmonary emboli.91,92 The risk of heparin-associated thrombocytopenia is more duration related than dose related. Heparin-associated thrombocytopenia occurs more frequently with unfractionated heparin when used for an extended duration than with LMWH used for an extended duration.93 When used for prophylaxis, there was a higher prevalence of heparin-associated thrombocytopenia inthose receiving unfractionated heparin $(1.6 \%, 57$ of 3463$)$ than in those receiving LMWH $(0.6 \%, 23$ of 3714).93 However, treatment resulted in only a small difference in the prevalence of heparinassociated thrombocytopenia comparing unfractionated heparin $(0.9 \%, 22$ of 2321$)$ with LMWH $(0.6 \%$, 18 of 3126).93 Acquired dysfibrinogenemia occurs most often in patients with severe liver disease.94 The impairment of the fibrinogen is a structural defect caused by an increased carbohydrate content impairing the polymerization of the fibrin, depending on the degree of abnormality of the fibrinogen molecule. 94

\section{Heart failure}

Congestive heart failure (CHF) is considered amajor risk factor for VTE.13,41,61,95,96 Among patients with established $\mathrm{CHF}$, those with lower ejection fractions had a higher risk of thromboembolic event. 97,98 However, some investigators did not evaluate CHF among the risk factors for VTE. ${ }^{99}$ The reported frequency of PE in patients with heart failure has ranged widely from $0.9 \%$ to $39 \%$ of patients. $13,97,98,100,101$ The reported frequency of DVT in patients with CHF also ranged widely from $10 \%$ to $59 \% .13,41,61$ The largest investigation was from the National Hospital Discharge Survey. ${ }^{102}$ Among 58,873,000 patients hospitalized with heart failure in short-stay hospitals from 1979 to 2003, 1.63\% had VTE (relative risk 5 1.47).102 The relative risk for VTE was highest in patients less than 40 years old (relative risk 5 6.91). Some showed the lower the ejection fraction, the greater the risk of VTE.103 Among 755,807 adults older than 20 years with heart failure who died from 1980 to 1998, PE was listed as the cause of death in 20,387 (2.7\%). 104 Assuming that the accuracy of death certificates was only $26.7 \%, 105$ the rate of death from PE in these patients may have been as high as $10.1 \%$. 
Therefore, the estimated death rate from PE in patients who died with heart failure was 3\% to $10 \%$. CHF seems to be a stronger risk factor in women. Dries and colleagues ${ }^{97}$ reported a higher proportion of PE in women $(24 \%)$ compared with men $(14 \%)$. We too showed a higher relative risk of PE and of DVT in women with CHF than in men.102 Although these data seemcompelling, multivariate logistic analysis failed to identify $\mathrm{CHF}$ as an independent risk factor for DVT or PE. ${ }^{43}$ However, it was a risk factor for postmortem VTE that was not a cause of death. ${ }^{43}$ In one study of pediatric patients with dilated cardiomyopathy awaiting transplant the incidence of pulmonary embolism was $13.9 \% 106$.

Heart failure is the second most common risk factor for VTE in hospitalized patients, as shown in ENDORSE.107

\section{COPD}

Hospitalized patients with exacerbations of COPD, when routinely evaluated, showed PE in $25 \%$ to $29 \% .108,109$ From 1979 to $2003,58,392,000$ adults older than 20 years were hospitalized with COPD in short-stay hospitals in the United States.110 PE was diagnosed in 381,000 $(0.65 \%)$ and DVT in 632,000 (1.08\%).110 The relative risk for PE in adults hospitalized with COPD was 1.92 and for DVT it was 1.30. Among those aged 20 to 39 years with COPD, the relative risk for PE was 5.34. Among patients with COPD aged 40 to 59 years, the relative risk for PE decreased to 2.02, and among patients aged 60 to 79 years the relative risk for PE was 1.23.110 The relative risk for DVT was also higher in patients with COPD aged 20 to 39 years (relative risk 5 2.58) than in patients aged 40 years or older (relative risk 0.92-1.17, depending on age).110 In young adults, other risk factors in combination with COPD are uncommon, so the contribution of COPD to the risk of PE becomes more apparent than in older patients. Although these data strongly suggest that COPD is a risk factor for PE and DVT, multivariate logistic analysis did not identify it as an independent risk factor.43 Others, with univariate analysis, did not identify COPD as a risk factor.61

Neuhaus et al. ${ }^{111}$ found pulmonary emboli in $27 \%$ of 66 autopsies performed in patients who had respiratory failure (not only as a decompensation of COPD) and died after admission to a Respiratory Intensive Care Unit.

The largest study was conducted by Schonhofer and Kohler 112 on a population of 196 patients admitted to a respiratory intensive care unit. The authors found a DVT rate of $10.7 \%$ as assessed by US. The majority ( $86 \%$ ) of cases were asymptomatic and, interestingly, almost all major clinical variables (such as age, weight, severity of dyspnea, lung function, situation of blood gases) failed to predict patients who were more likely to develop DVT.

\section{Stroke}

There is considerable evidence that in spinal cord injury patients interruption of neurologic impulses and the ensuing paralysis cause profound metabolic changes in blood vessels accountable for venous thrombosis.

Vascular adaptations to inactivity and muscle atrophy, rather than the effect of a nonworking leg-muscle pump and sympathetic denervation, cause thrombosis, indicating that thrombosis established through venous incompetence cannot be reversed by anticoagulation alone. 
Spinal cord injuries with paralysis result in an immobile state with retardation of the blood flow caused by the relaxation of muscle and the atony of blood vessels. It is not surprising that spinal cord injuries are frequently complicated by the development of venous thrombosis, which is inevitably linked to hospitalization, immobilization, vein wall damage, stasis, and hypercoagulability. Deep vein thrombosis and pulmonary emboli remain the major complications in spinal cord injuries below the C2 through T12 vertebrae associated with motor complete or motor nonfunctional paralysis. 113,114,115,116,117,118,119 Two surprising findings set spinal cord injury apart from other risk factors for venous thrombosis: incidence of leg DVT and pulmonary embolism in spinal cord injury is three times higher than in the general population.

Patients with stroke are at particular risk of developing DVT and PE because of limb paralysis, prolonged bed rest, and increased prothrombotic activity.120 Among 14,109,000 patients with ischemic stroke hospitalized in short-stay hospitals from 1979 to 2003, VTE was diagnosed in 165,000 (1.17\%).121 Among 1,606,000 patients with hemorrhagic stroke, the incidence of VTE was higher (1.93\%).

Among patients with ischemic stroke who died from 1980 to 1998, PE was the listed cause of death in 11,101 of 2,000,963 (0.55\%).122 Based on an assumed sensitivity of death certificates for fatal PE of $26.7 \%$ to $37.2 \%, 105,123$ the corrected rate of fatal PE was $1.5 \%$ to $2.1 \%$. Death rates from PE among patients with ischemic stroke decreased from 1980 to 1998, suggesting effective use of antithrombotic prophylaxis.

\section{Cancer}

Cancer is a major risk factor of venous thromboembolism (VTE) ${ }^{124,125}$ as defined by deepvein thrombosis (DVT) - including central venous catheter (CVC) related thrombosis - or pulmonaryembolism (PE), which occur in 4 to $20 \%$ of cancer patients 126,127 .

\subsection{Cancer-related factors}

\subsubsection{Site of cancer}

In studies looking at pooled groups of patients with different types of malignancy, the rate of VTE is consistently highest in patients with cancer of the pancreas, stomach, brain, kidney, uterus, lung or ovary 128,129,130,131.

Both large retrospective studies by Stein et al and Chew et al based on discharge claims databases reported the highest rates of VTE in patients with pancreatic cancer $(4.3 \%$ and $5.3 \%$, respectively). Patients with stomach cancer had the second and third highest risk of developing VTE in these studies 128,132. In patients with testicular and lung cancer, those with metastases to the liver and brain were shown to have higher rates of VTE compared with patients with other sites of metastases 133,134 . The rates of VTE for specific types of cancer have been reported in many studies.

\subsubsection{Cancer stage}

Multiple studies have shown an increased risk of VTE in patients with advanced-stage cancer. In a retrospective study of over 500000 patients from the California Cancer Registry, patients with metastatic cancer stage were twice as likely to have developed VTE in the year 
prior to diagnosis of cancer ${ }^{135}$. In a population-based case-control study of patients with newly diagnosed VTE, including 389 patients with cancer, those with distant metastases had a higher risk of VTE (OR 19.8, CI 2.6-149) ${ }^{136}$.

A multicentre retrospective study of VTE in hospitalized cancer patients reported an incidence of $10.3 \%$ in patients with advanced-stage cancer compared with $5.6 \%$ in patients with localized disease $(\mathrm{P}<0.0005$, OR 1.92, CI 1.21-3.04) 137 , and these findings have been supported by other large studies in hospitalized cancer patients ${ }^{138}$. Other studies in ovarian, colorectal, pancreatic, lung and breast cancer support the finding that advanced-stage disease increases the risk of cancer- associated VTE 139,140,141,142,143,144.

\subsection{Histology}

In certain types of cancer, higher rates of VTE are found in some histological subtypes compared with others. For example, in patients with non-small-cell lung cancer, $9.9 \%$ of those with adenocarcinoma subtype develop VTE in the first 6 months after diagnosis compared with $7.7 \%$ with squamous cell carcinoma (HR 1.9, CI 1.7-2.1) ${ }^{141}$.Inbreast and colon cancer patients, the type of histology does not predict for the incidence of cancerassociated VTE, but VTE-associated mortality rates are higher in patients with certain histological subtypes 141,143 .

\subsection{Time after diagnosis}

Several studies have demonstrated that the risk of VTE is highest in the initial time period following cancer diagnosis. In a population-based study of patients with thrombosis, the risk of developing VTE was highest in the first few months following the initial diagnosis of malignancy. A retrospective analysis of over 200000 cancer patients from the California Cancer Registry revealed that the rate of VTE per patient-year in the first year after diagnosis of cancer was 3.3, compared with 0.8 in the second year after diagnosis 145 . The rate of VTE in patients with colon cancer during the first 6 months after diagnosis is 5.0/100 patient-years, but this drops off dramatically to $1.4 / 100$ patient-years in the next 6- month period ${ }^{143}$.

\subsection{Chemotherapy}

Chemotherapy is one of the most important factors in VTE risk stratification of cancer patients. Large population-based studies in groups of pooled cancer patients have demonstrated a significantly increased risk in patients receiving chemotherapy. Heit et al used a population-based study of patients with a new diagnosis of VTE, $23 \%$ of which had a diagnosis of active malignancy, to demonstrate a significantly increased risk of VTE in those on chemotherapy (OR 6.5, CI 2.11-20) ${ }^{146}$.

Studies in specific types of cancer and with specific antineoplastic agents have also supported the role of chemotherapy in predicting the risk of cancer-associated VTE. Two prospective studies of breast cancer patients demonstrated that the risk of VTE in patients receiving chemotherapy in addition to tamoxifen or surgery increased two- to seven-fold 147,148. A recent meta-analysis of breast cancer patients revealed that use of adjuvant hormonal therapy was associated with a 1.5-7-fold increased risk of VTE ${ }^{149}$. 


\subsection{Surgery}

Surgery is a well-known risk factor for development of VTE in patients without cancer. The incidence of DVT in cancer patients undergoing general surgery is estimated at $37 \%$ compared with $20 \%$ in patients without cancer 150 . Factors related to immobility, tissue destruction and venous stasis are likely to be related to the increased risk of VTE after surgery.

\subsection{Indwelling catheters}

Indwelling central venous catheters (CVC) greatly facilitate treatment in cancer patients, but they are also associated with complications including a significant risk of catheter-associated thrombosis. The incidence of symptomatic catheter-related DVT in adult patients ranges from $0.3 \%$ to $28 \%$, while the rate of catheter-related DVT assessed by venography is 27 $66 \% 151$.

Studies have not consistently demonstrated an association between use of haematopoietic growth factors and risk of cancer-associated VTE. İn a prospective study of ambulatory patients receiving chemotherapy, both the use of white cell growth factors and the use of red cell growth factors or decreased haemoglobin were independent predictors of VTE in multivariate analysis ${ }^{152}$. This association was only significant in types of cancer already known to have high rates of thrombosis, and it is possible that these agents are used more frequently in patients with other markers of poor prognosis or more aggressive disease.

\subsection{Platelet and leukocyte counts}

The authors' group was the first to identify an elevated prechemotherapy platelet count as a significant risk factor for cancer-associated thrombosis ${ }^{152}$. In a prospective study of outpatients receiving chemotherapy, $21.9 \%$ had a platelet count of $350000 / \mathrm{mm} 3$ or more prior to starting chemotherapy. The incidence of VTE was 3.98\% (1.66\% per month) for these patients, which was significantly higher than the rate of $1.25 \%(0.52 \%$ per month) for patients with a prechemotherapy platelet count of less than $200000 / \mathrm{mm} 3$ (P for trend $1 / 4$ 0.0003). The distribution of rechemotherapy platelet counts in patients who subsequently developed VTE was significantly higher than that for patients who did not develop VTE ( $t$ test $\mathrm{P} 1 / 40.002$, Wilcoxon rank sum test $\mathrm{P} 1 / 40.0002$ ).

\subsection{Tissue factor}

Tissue factor (TF), a transmembrane glycoprotein present on subendothelial tissue, platelets and leukocytes, is a key component in the initiation of coagulation and may play a role in cancer- associated thrombosis $153-155$. The authors recently demonstrated a correlation between the level of TF expression in pancreatic tumours and subsequent development of VTE 156. VTE was four-fold more common (P 1/4 0.04) among patients with high TFexpressing carcinomas $(26.5 \%)$ than among patients with low TF-expressing carcinomas $(5.5 \%)$.

From 1979 to 1999 , among 40,787,000 patients hospitalized in short-stay hospitals with any of 19 malignancies studied, 827,000 (2.0\%) had VTE.157 This was twice the incidence in patients without these malignancies.157 The highest incidence of VTE was in patients with 
carcinoma of the pancreas $(4.3 \%)$ and the lowest incidences were in patients with carcinoma of the bladder and carcinoma of the lip, oral cavity, or pharynx $(<0.6 \%$ to $1.0 \%)$. Incidences with cancer were not age dependent.157 Myeloproliferative diseaseand lymphoma were associated with relative risks for VTE of 2.9 and 2.5, respectively157 Leukemia was associated with a lower relative risk (1.7). Based on death certificates from 1980 to 1998 among patients who died with cancer, PE was the listed cause of death in $0.21 \% .158$ Adjustment of the data for the frailty of the diagnosis of fatal PE based on death certificates indicated a likely range of $0.31 \%$ to $1.97 \% .158$

\section{Pregnancy}

Pregnancy-associated DVT based on data from the National Hospital Discharge Survey was diagnosed in 93,000 of $80,798,000$ women $(0.12 \%)$ from 1979 to 1999.151 The rate of pregnancyassociated DVT (vaginal delivery and cesarean section) increased from 1982 to 1999, although the rate of nonpregnancy-associated DVT decreased for most of this period. Some showed the rate of pregnancy-associated DVT was twice the rate of nonpregnancyassociated DVT.159 A 6-fold increase in the rate of thromboembolism during pregnancy and the puerperium compared with nonpregnant women has been reported by others.160 Although the rate of pregnancy-associated DVT was higher than the rate of nonpregnancyassociated DVT, the rate of pregnancyassociated PE was lower than

Pathophysiology of venous thromboembolism during Pregnancy:

Increased venous distensibility and capacity, with a resultant reduction in the velocity of blood flow in the lower limbs, are demonstrable from the first trimester of pregnancy 162,163. These changes are compounded by a $20-25 \%$ increase in the overall circulatory volume during pregnancy ${ }^{164}$. Obstruction of the inferior vena cava by the enlarging gravid uterus may also result in increased stasis ${ }^{165}$. Compression of the left iliac vein by the right iliac artery as they cross 166 may explain the preponderance of left leg DVT during pregnancy 161,167.

Altered levels of coagulation factors have been described both during pregnancy and postpartum. Hypercoagulability is thought to be promoted by increases in coagulation factors such as fibrinogen, von Willebrand factor, and factor VIII:C 168,169-171, as well as by decreases in natural inhibitors of coagulation such as protein $S 172$ and the development of an acquired resistance to the endogenous anticoagulant, activated protein $C{ }^{173}$. In addition, a reduction in global fibrinolytic activity has been described during pregnancy 174 , perhaps as a consequence of increases in the levels of plasminogen activator inhibitor 1 (PAI 1) and plasminogen activator inhibitor 2 (PAI 2) ${ }^{174-176}$, the latter being produced by the placenta.

Exogenous risk factors also appear to determine the thrombotic risk associated with pregnancy. In a retrospective cohort study of unselected consecutive patients with confirmed pregnancy-related venous thromboembolism, approximately two-thirds of patients had an identifiable acquired risk factor (for example, age over 35 years, intercurrent illness, immobility, increased parity or caesarean section) ${ }^{177}$.

The reason for this difference is unknown and could reflect difference of the natural history of DVT in pregnancy. It also could reflect a reluctance to expose pregnant women to ionizing radiation associated with imaging for $\mathrm{PE}$, resulting in a decreased frequency of diagnosis of PE. The rate of pregnancy-associated DVT was higher among women aged 35 to 44 years than in younger women. The rate of pregnancyassociated DVT among black 
women was higher than among white women.159,178,179 DVT was more frequent among women who underwent cesarean section $(104 / 100,000 / y)$ than those who underwent vaginal delivery $(47 / 100,000 / y) .159$ VTE in pregnancy is discussed in detail in the article by Marik elsewhere in this issue.

\section{Surgery and trauma}

In PIOPED, trauma of the lower extremities was a predisposing factor in $10 \%$ of patients with PE, and in PIOPED II trauma of the lower extremities or pelvis was a predisposing factor in 14\%.180,181 Surgery within 3 months of the acute PE was a predisposing factor in $54 \%$ in PIOPED and in 23\% in PIOPED II.180,181 The prevalence of VTE following various categories of surgery and trauma has been reviewed in detail by Geerts and colleagues 182 .

\section{Central venous access}

The use of long-term venous access is now an integral component of treatment for patients receiving long-term antibiotic administration or hyperalimentation or undergoing chemotherapy. Externalized tunneled catheters were introduced almost 30 years ago, but required daily cleaning and frequent flushing 190,191 . On average, deep venous thrombosis (DVT) can complicate approximately $2 \%-6.7 \%$ of such port placements ${ }^{192}-194$, although literature reports have ranged from $0 \%$ to $26 \% 195-198$. In 1991, Monreal et al. 199 observed that 4 of 30 consecutive patients with upper extremity deep venous thrombosis (DVT) had PE $(13.3 \%)$, but more importantly, all these 4 occurred in 20 catheter related DVT patients $(20 \%)$, while none of 10 patients with primary upper extremity DVT had PE.

\section{Medical illnesses}

\subsection{Inflammatory bowel disease}

The incidence of VTE among hospitalized medical patients with ulcerative colitis was $1.9 \%$ and the incidence with Crohn disease was lower (1.2\%).200 Among medical patients who had neither ulcerative colitis nor Crohn disease the incidence was 1.1\%.200 The relative risk of VTE among patients with ulcerative colitis compared with patients who did not have inflammatory bowel disease was 1.9 and with Crohn disease it was 1.2. Among patients younger than 40 years with ulcerative colitis, the relative risk of VTE compared with patients who did not haveinflammatory bowel disease was 2.96 and in patients younger than 40 years with Crohn disease the relative risk was 2.23.200

\subsection{Liver disease}

Patients with chronic liver disease (both alcoholic and nonalcoholic) seem to have a lower risk of PE than patients without liver disease,43,201 but data are inconsistent.202 Chronic liver disease may result in impaired production of vitamin- $\mathrm{K}$ dependent procoagulant factors.203 However, decreased production of vitamin-K dependent endogenous anticoagulants, such as protein $\mathrm{C}$, protein S, and antithrombin III, may counter the hypocoagulability in such patients. 203 Other prothrombotic factors may counteract the impaired production of vitamin Kdependent procoagulant factors including lupus anticoagulant, activated protein C resistance, PT20210A mutation, Factor V Leiden, MTHFR 
mutation, and increased levels of factor VIII.204 Based on data from the National Hospital Discharge Survey, among 4,927,000 hospitalized patients with chronic alcoholic liver disease from 1979 to 2006, the prevalence of VTE was $0.6 \%$ and among 4,565,000 hospitalized patients with chronic nonalcoholic liver disease it was $0.9 \% .201$ The prevalence of VTE was higher in those with chronic alcoholic liver disease than with nonalcoholic liver disease, but the difference was small and of no clinical consequence.201

Both showed a lower prevalence of VTE than in hospitalized patients with most other medical diseases. It may be that both chronic alcoholic liver disease and chronic nonalcoholic liver disease have protective antithrombotic mechanisms although the mechanisms differ.

\subsection{Hypothyroidism}

Among 19,519,000 hospitalized patients with a diagnosis of hypothyroidism from 1979 to 2005, 119,000 (0.61\%) had PE (relative risk 5 1.64).205 DVT was diagnosed in $1.36 \%$ of hypothyroid patients (relative risk 5 1.62).205 The relative risk for PE in patients with hypothyroidism was highest in patients younger than 40 years (relative risk 53.99 ) and the relative risk for DVT was also highest in patients younger than 40 years (relative risk 52.25 ). Hyperthyroidism was not associated with an increased risk for VTE (relative risk 50.98 ).

\subsection{Rheumatoid arthritis}

Rheumatoid arthritis is not generally considered a risk factor for VTE, although abnormalities of coagulation factors have been found in patients with rheumatoid arthritis.206,207 Among 4,818,000 patients hospitalized in short-stay hospitals from 1979 to 2005 with rheumatoid arthritis who did not have joint surgery, the incidence of PE was $2.3 \%$, and the relative risk of VTE compared with those who did not have rheumatoid arthritis was 1.99.208 Among patients younger than 50 years the relative risk was higher (2.13).208

\subsection{Diabetes mellitus}

Among 92,240,000 patients with diabetes mellitus hospitalized from 1979 to 2005, 1,267,000 (1.4\%) had VTE.209 The relative risk for VTE was increased only in patients younger than 50 years and was highest in patients aged 20 to 29 years (relative risk 5 1.73). In patients with diabetes mellitus who did not have obesity, stroke, heart failure, or cancer, compared with those who did not have diabetes mellitus and did not have any of these comorbid conditions, the relative risk for VTE was 1.52 in patients aged 20 to 29 years and 1.19 in patients 30 to 39 years. In older patients, the relative risk of VTE in patients with diabetes mellitus was not increased.209 Among all adults with diabetes mellitus, the relative risk of VTE was 1.05.209

\subsection{Human immunodeficiency virus}

Among 2,429,000 patients older than 18 years hospitalized in short-stay hospitals from 1990 through 2005 with human immunodeficiency virus (HIV) infection; the prevalence of VTE was $1.7 \%$ (relative risk 51.21 ).210 The prevalence of VTE in patients aged 30 to 49 years was also $1.7 \%$, but the relative risk compared with patients who did not have HIV infection was higher (1.65).210 


\subsection{Nephrotic syndrome}

From 1979 to 2005, 925,000 patients were discharged from short-stay hospitals with nephrotic syndrome and 14,000 (1.5\%) had DVT (relative risk 5 1.72).211 In patients aged 18 to 39 years the relative risk for DVT was 6.81.211 Renal vein thrombosis was so uncommon that too few were reported to calculate its prevalence. Therefore, PE, if it occurs, is likely to be due to emboli from the lower extremities and not the renal vein.

\subsection{Sickle cell disease}

Sickle cell disease does not seem to be a risk factor for DVT.212 Among 1,804,000 patients hospitalized in short-stay hospitals with sickle cell disease from 1979 to 2003, 11,000 (0.61\%) had a discharge diagnosis of DVT, which was not more than in African Americans without sickle cell disease (0.81\%).212 Among patients with sickle cell disease, a discharge diagnosis of PE was made in $0.50 \%$ compared with $0.33 \%$ who did not have sickle cell disease. Regarding patients younger than 40 years, $0.44 \%$ had PE, whereas among patients who did not have sickle cell disease, $0.12 \%$ had PE.212 The higher prevalence of apparent PE in patients with sickle cell disease compared with African American patients the same age who did not have sickle cell disease, and the comparable prevalence of DVT in both groups, is compatible with the concept that thrombosis in situ may be present in many.

\subsection{Systemic lupus erythematosus}

Systemic lupus erythematosus is believed to be independently associated with the risk of developing DVT.61 The odds ratio for DVT in patients with systemic lupus erythematosus, compared with those without it, was 4.3.61

\subsection{Behçet disease}

Behcet disease is a rare multisystem inflammatory disorder of unknown cause.213 VTE occurs in about one-fifth of patients with Behc, et disease. 213

\subsection{Paroxysmal nocturnal hemoglobinuria}

Review of 13 retrospective studies of patients with paroxysmal nocturnal hemoglobinuria showed a $30 \%$ prevalence of venous thrombotic events in patients from Western nations.214 The majority was within the hepatic and mesenteric veins.214

\subsection{Buerger disease}

PE associated with thromboangiitis obliterans (Buerger disease) is rare, and to our knowledge, limited to a case report.215

\section{Sepsis}

Initiation of coagulation takes place when TF is exposed, such as by fibroblasts, when there is tissue damage or by cytokine-stimulated monocytes and endothelial cells ${ }^{216}$, as in sepsis. While TF is the major initiator of coagulation, endotoxin, foreign bodies, and negatively charged particles may initiate coagulation via contact system activation. TF binds to factor 
VIIa, and this complex (TF:VIIa) may then activate factor $\mathrm{X}$ and factor IX ${ }^{217}$. Factor Xa, associated with factor $\mathrm{Va}$, forms the prothrombinase complex, which subsequently turns prothrombin into thrombin.

The relationship between coagulation and inflammation is complex and, as yet, not completely understood. It is known that blood clotting not only leads to fibrin deposition and platelet activation, but it also results in vascular cell activation, which contributes to leukocyte activation ${ }^{218}$. On the other hand, inflammation can induce TF expression in monocytes, via nuclear factor kappa-B (NF-kB) activation, thus initiating coagulation ${ }^{216}$.

Examples of this interaction are readily seen. First, leukocytes are found at relatively high concentrations in venous thrombi, and leukocytes and activated platelets can form rosettes mediated by P-selectin expression on the surface of the activated platelet 219,220.

These microscopic observations are probably elicited from the actions of thrombin, which can activate platelets and endothelium, increasing the surface expression of P-selectin 221,222. $\mathrm{P}$ - electin is the primary initial mediator of leukocyte-endothelial cell rolling and is critical for leukocyte adhesion. Second, TF:VIIa and factor Xa have been shown to activate cells and generate responses similar to those mediated by thrombin ${ }^{218}$. Third, GAG and TM expression on cell surfaces are inhibited by inflammatory cytokines 223,224,225,226 and lipopolysaccharide (LPS) ${ }^{227}$, thus blocking the augmentation of AT action by GAG, and APC formation by TM.

\section{References}

[1] Fowkes FJI, Price JF, Fowkes FGR. Incidence of diagnosed deep vein thrombosis in the general population: systematic review. Eur J Vasc Endovasc Surg 2003; 25: 1-5.

[2] Heit JA, Silverstein MD, Mohr DN, et al. The epidemiology of venous thromboembolism in the community. Thromb Haemost 2001; 86: 452-63.

[3] Stein PD, Patel KC, Kalra NK, et al. Deep venous thrombosis in a general hospital. Chest 2002; 122: 960-62.

[4] Kniffin WD, Baron JA, Barrett J, Birkmeyer JD, Anderson FA Jr. The epidemiology of diagnosed pulmonary embolism and deep venous thrombosis in the elderly. Arch Intern Med 1994; 154: 861-66.

[5] Heit JA, O'Fallon WM, Petterson TM, et al. Relative impact of risk factors for deep vein thrombosis and pulmonary embolism: a population-based study. Arch Intern Med 2002; 162: 1245-48.

[6] Cushman M, Tsai AW, White RH, et al. Deep vein thrombosis and pulmonary embolism in two cohorts: the longitudinal investigation of thromboembolism etiology. Am J Med 2004; 117: 19-25.

[7] Patel RK, Lambie J, Bonner L, Arya R. Venous thromboembolism in the black population. Arch Intern Med 2004; 164: 1348-49.

[8] Klatsky AL, Armstrong MA, Poggi J. Risk of pulmonary embolism and/or deep venous thrombosis in Asian-Americans. Am J Cardiol 2000; 85: 1334-37.

[9] Anderson FA, Wheeler HB, Goldberg RJ, et al. A population-based perspective of the hospital incidence and case-fatality rates of deep vein thrombosis and pulmonary embolism: the Worcester DVT Study. Arch Intern Med 1991; 151: 933-38. 
[10] Kyrle PA, Minar E, Bialonczyk C, Hirschl M, Weltermann A, Eichinger S. The risk of recurrent venous thromboembolism in men and women. $N$ Engl J Med 2004; 350: 2558-63.

[11] Anderson FA Jr, Spencer FA. Risk factors for venous thromboembolism. Circulation 2003;107:I9 -I16.

[12] Coleridge-Smith PD, Hasty JH, Scurr JH. Venous stasis and vein lumen changes during surgery. Br J Surg 1990;77:1055-9.

[13] Coleridge Smith PD, Hasty JH, Scurr JH. Deep vein thrombosis: effect of graduated compression stockings on distension of the deep veins of the calf. Br J Surg 1991;78:724-6.

[14] Comerota AJ, Stewart GJ, Alburger PD, et al. Operative venodilation: a previously unsuspected factor in the cause of postoperative deep vein thrombosis. Surgery 1989;106:301-9.

[15] Comerota AJ, Stewart GJ, White JV. Combined dihydroergotamine and heparin prophylaxis of postoperative deep vein thrombosis: proposed mechanism of action. Am J Surg 1985;150:39-44.

[16] Stamatakis JD, Kakkar VV, Sagar S, et al. Femoral vein thrombosis and total hip replacement. BMJ 1977;2:223-5.

[17] Mammen EF. Pathogenesis of venous thrombosis. Chest 1992;102:640S-4S.

[18] Mackman N. Role of tissue factor in hemostasis, thrombosis, and vascular development. Arterioscler Thromb Vasc Biol 2004;24:1015-22.

[19] Geerts WH, Bergqvist D, Pineo GF, et al. Prevention of venous thromboembolism: American College of Chest Physicians Evidence-Based Clinical Practice Guidelines. Chest 2008;133:381S- 453S.

[20] Thromboembolic Risk Factors (THRIFT) Consensus Group. Risk of and prophylaxis for venous thromboembolism in hospital patients. BMJ 1992;305:567-74.

[21] Wheeler HB. Diagnosis of deep vein thrombosis. Review of clinical evaluation and impedance plethysmography. Am J Surg 1985;150:7-13.

[22] Nguyen GC, Sam J. Rising prevalence of venous thromboembolism and its impact on mortality among hospitalized inflammatory bowel disease patients. Am J Gastroenterol 2008;103:2272- 80.

[23] Kröger K, Weiland D, Ose C, et al. Risk factors for venous thromboembolic events in cancer patients. Ann Oncol 2006;17:297-303.

[24] Kovacevich GJ, Gaich SA, Lavin JP, et al. The prevalence of thromboembolic events among women with extended bed rest prescribed as part of the treatment for premature labor or preterm premature rupture of membranes. Am J Obstet Gynecol 2000;182:1089 -92.

[25] Anderson FA Jr, Wheeler HB, Goldberg RJ, et al. A population-based perspective of the hospital incidence and case-fatality rates of deep vein thrombosis and pulmonary embolism. The Worcester DVT Study. Arch Intern Med 1991;151:933- 8.

[26] Borow M, Goldson H. Postoperative venous thrombosis. Evaluation of five methods of treatment. Am J Surg 1981;141:245-51.

[27] Borow M, Goldson HJ. Prevention of postoperative deep venous thrombosis and pulmonary emboli with combined modalities. Am Surg 1983;49:599-605. 
[28] Sugerman HJ, Sugerman EL, Wolfe L, et al. Risks and benefits of gastric bypass in morbidly obese patients with severe venous stasis disease. Ann Surg 2001;234:416.

[29] Geerts WH, Heit JA, Clagett GP, et al. Prevention of venous thromboembolism. Chest 2001;119:132S-75S.

[30] Caprini JA. Thrombosis risk assessment as a guide to quality patient care. Dis Mon 2005;51:70-8.

[31] Stein PD, Beemath A, Matta F, et al. Clinical characteristics of patient with acute pulmonary embolism: data from PIOPED II. Am J Med 2007;120:871e9.

[32] Stein PD, Terrin ML, Hales CA, et al. Clinical, laboratory, roentgenographic and electrocardiographic findings in patients with acute pulmonary embolism and no pre-existing cardiac or pulmonary disease. Chest 1991;100:598e603

[33] Heit JA, Silverstein MD, Mohr DN, et al. The epidemiology of venous thromboembolism in the community. Thromb Haemost 2001;86:452e63.

[34] Anderson FA Jr, Wheeler HB, Goldberg RJ, et al. The prevalence of risk factors for venous thromboembolism among hospital patients. Arch Intern Med 1992;152:1660e4.

[35] Hedley AA, Ogden CL, Johnson CL, et al. Prevalence of overweight and obesity among US children, adolescents, and adults, 1999e2002. JAMA 2004;291:2847e50.

[36] Goldhaber SZ, Grodstein F, Stampfer MJ, et al. A prospective study of risk factors for pulmonary embolism in women. JAMA 1997;277:642e5.

[37] Abdollahi M, Cushman M, Rosendaal FR. Obesity: risk of venous thrombosis and the interaction with coagulation factor levels and oral contraceptive use. Thromb Haemost 2003;89:493e8.

[38] Coon WW, Coller FA. Some epidemiologic considerations of thromboembolism. Surg Gynecol Obstet 1959;109:487e501.

[39] Basili S, Pacini G, Guagnano MT, et al. Insulin resistance as a determinant of platelet activation in obese women. J Am Coll Cardiol 2006;48:2531e8.

[40] Hansson PO, Eriksson H, Welin L, et al. Smoking and abdominal obesity: risk factors for venous thromboembolism among middle-aged men: "the study of men born in 1913". Arch Intern Med 1999;159:1886e90.

[41] Samama MM. An epidemiologic study of risk factors for deep vein thrombosis in medical outpatients: the Sirius study. Arch Intern Med 2000;160: 3415e20.

[42] Kabrhel C, Varraso R, Goldhaber SZ, et al. Prospective study of BMI and the risk of pulmonary embolism in women. Obesity (Silver Spring) 2009; 17:2040e6.

[43] Heit JA, Silverstein MD, Mohr DN, et al. Risk factors for deep vein thrombosis and pulmonary embolism: a population-based case-control study. Arch Intern Med 2000;160:809e15.

[44] US Department of Health and Human Services. Public Health Service, National Center for Health Statistics National Hospital Discharge Survey 1979-2006 Multi-year Public-Use Data File Documentation. Available at: http://www.cdc.gov/nchs/about/major/hdasd/nhds.htm. Accessed April 28, 2010.

[45] Stein PD, Beemath A, Olson RE. Obesity as a risk factor in venous thromboembolism. Am J Med 2005;118:978e80. 
[46] Farmer RD, Lawrenson RA, Todd JC, et al. A comparison of the risks of venous thromboembolic disease in association with different combined oral contraceptives. Br J Clin Pharmacol 2000;49:580e90.

[47] Pannaciulli N, De Mitrio V, Marino R, et al. Effect of glucose tolerance status on PAI-1 plasma levels in overweight and obese subjects. Obes Res 2002; 10:717e25.

[48] De Pergola G, Pannacciulli N. Coagulation and fibrinolysis abnormalities in obesity. J Endocrinol Invest 2002;25:899e904.

[49] Mertens I, Van Gaal LF. Obesity, haemostasis and the fibrinolytic system. Obes Rev 2002;3:85e101.

[50] Bara L, Nicaud V, Tiret L, et al. Expression of a paternal history of premature myocardial infarction on fibrinogen, factor VIIC and PAI-1 in European offspringethe EARS study. European Atherosclerosis Research Study Group. Thromb Haemost 1994;71:434e40.

[51] Rosengren A, Frede'n M, Hansson PO, et al. Psychosocial factors and venous thromboembolism: a long-term follow-up study of Swedish men. J Thromb Haemost 2008;6:558e64.

[52] Glynn RJ, Rosner B. Comparison of risk factors for the competing risks of coronary heart disease, stroke, and venous thromboembolism. Am J Epidemiol 2005;162:975e82.

[53] Homans J. Thrombosis of the deep leg veins due to prolonged sitting. N Engl J Med 1954;250:148e9.

[54] Tardy B, Page Y, Zeni F, et al. Phlebitis following travel. Presse Med 1993;22:811e4.

[55] Simpson K. Shelter deaths from pulmonary embolism. Lancet 1940;2:744.

[56] Cruickshank JM, Gorlin R, Jennett B. Air travel and thrombotic episodes: the economy class syndrome. Lancet 1988;2:497e8.

[57] Collins J. Thromboembolic disease related to air travel: what you need to know. Semin Roentgenol 2005;40:1e2.

[58] Hertzberg SR, Roy S, Hollis G, et al. Acute symptomatic pulmonary embolism associated with long haul air travel to Sydney. Vasc Med 2003;8:21e3.

[59] Perez-Rodriguez E, Jimenez D, Diaz G, et al. Incidence of air travel-related pulmonary embolism at the Madrid-Barajas airport. Arch Intern Med 2003; 163:2766e70.

[60] Hughes RJ, Hopkins RJ, Hill S, et al. Frequency of venous thromboembolism in low to moderate risk long distance air travellers: the New Zealand Air Traveller's Thrombosis (NZATT) study. Lancet 2003;362:2039e44.

[61] Cogo A, Bernardi E, Prandoni P, et al. Acquired risk factors for deep-vein thrombosis in symptomatic outpatients. Arch Intern Med 1994;154:164e8.

[62] Lewis MA. The epidemiology of oral contraceptive use: a critical review of the studies on oral contraceptives and the health of young women. Am J Obstet Gynecol 1998;179:1086e97.

[63] Realini JP, Goldzieher JW. Oral contraceptives and cardiovascular disease: a critique of the epidemiologic studies. Am J Obstet Gynecol 1985;152:729e98.

[64] Vandenbroucke JP, Rosing J, BloemenkampK W, et al. Oral contraceptives and the risk of venous thrombosis. N Engl J Med 2001;344:1527e35.

[65] Gerstman BB, Piper JM, Tomita DK, et al. Oral contraceptive estrogen dose and the risk of deep venous thromboembolic disease. Am J Epidemiol 1991;133:32e7. 
[66] Lidegaard O, Edstrom B, Kreiner S. Oral contraceptives and venous thromboembolism. A casecontrol study. Contraception 1998;57:291e301.

[67] World Health Organization Collaborative Study of Cardiovascular Disease and Steroid Hormone Contraception. Venous thromboembolic disease and combined oral contraceptives: results of international multicentre case-control study. Lancet 1995;346:1575e82.

[68] Helmrich SP, Rosenberg L, Kaufman DW, et al. Venous thromboembolism in relation to oral contraceptive use. Obstet Gynecol 1987;69:91e5.

[69] Pomp ER, le Cessie S, Rosendaal FR, et al. Risk of venous thrombosis: obesity and its joint effect with oral contraceptive use and prothrombotic mutations. Br J Haemotol 2007;139:289e96.

[70] Lidegaard O, Edstrom B, Kreiner S. Oral contraceptives and venous thromboembolism: a fiveyear national case-control study. Contraception 2002;65:187e96.

[71] Nightingale AL, Lawrenson RA, Simpson EL, et al. The effects of age, body mass index, smoking and general health on the risk of venous thromboembolism in users of combined oral contraceptives. Eur J Contracept Reprod Healthcare 2000;5:265e74.

[72] Decensi A, Maisonneuve P, Rotmensz N, et al. Italian Tamoxifen Study Group. Effect of tamoxifen on venous thromboembolic events in a breast cancer prevention trial. Circulation 2005;111:650e6.

[73] Duggan C, Marriott K, Edwards R, et al. Inherited and acquired risk factors for venous thromboembolic disease among women taking tamoxifen to prevent breast cancer. J Clin Oncol 2003;21:3588e93.

[74] Meier CR, Jick H. Tamoxifen and risk of idiopathic venous thromboembolism. Br J Clin Pharmacol 1998;45:608e12.

[75] Daly E, Vessey MP, Hawkins MM, et al. Risk of venous thromboembolism in users of hormone replacement therapy. Lancet 1996;348:977e80.

[76] Varas-Lorenzo C, García-Rodriguez L, Cattaruzzi C, et al. Hormone replacement therapy and the risk of hospitalization for venous thromboembolism: a populationbased study in southern Europe. Am J Epidemiol 1998;147:387e90.

[77] Grady D, Wenger NK, Herrington D, et al. Postmenopausal hormone therapy increases risk for venous thromboembolic disease. The Heart and Estrogen/progestin Replacement Study. Ann Intern Med 2000;132:689e96.

[78] Peverill RE. Hormone therapy and venous thromboembolism. Best Pract Res Clin Endocrinol Metab 2003;17:149e64.

[79] Whiteman T, Hassouna HI. Hypercoagulable States, Hem/Onc Clin N Am. 2000. 14: 2.

[80] Bick RL. Prothrombin G20210A mutation, antithrombin, heparin cofactor II, protein C, and protein S defects, Hematol Oncol Clin N Am. 2003. 17: 9-36.

[81] Johnson CM, Mureebe L, Silver D. Hypercoagulable states: A review, Vasc Endovasc Surg. 2005. 39: 123-133.

[82] Bick RL. Clinical relevance of antithrombin III, Semin Thromb Hemost. 1982. 8: 276.

[83] Seligsohn U, Lubetsky A. Genetic susceptibility to venous thrombosis, N Engl J Med. 2001. 344: 1222-1231.

[84] Bick RL. Prothrombin G20210A mutation, antithrombin, heparin cofactor II, protein C, and protein S defects, Hematol Oncol Clin N Am. 2003. 17: 9-36. 
[85] Nicolaes GAF, Dahlback B. Activated protein C resistance (FVLeiden) and thrombosis: Factor $\mathrm{V}$ mutations causing hypercoagulable states, Hematol Oncol Clin N Am. 2003. 17: 37-61.

[86] Koppelman SJ, Hackeng TM, Sixma JJ et al. Inhibition of the intrinsic factor X activating complex by protein S: Evidence for specifi c binding of protein $\mathrm{S}$ to factor VIII, Blood. 1995. 86:1062-1071.

[87] Allaart CF, Poort SR, Rosendaal FR et al. Increased risk of venous thrombosis in carriers of hereditary protein C defi ciency defect, Lancet. 1993. 341: 134-138.

[88] Silver D, Vouyouka A. The caput medusae of hypercoagulability, J Vasc Surg. 2000. 31: 396-495.

[89] Greaves M. Antiphospholipid antibodies and thrombosis. Lancet 1999;353:1348e53.

[90] Levine JS, Branch DW, Rauch J. The antiphospholipid syndrome. N Engl J Med 2002;346: 752e63.

[91] Asherson RA, Khamashta MA, Ordi-Ros J, et al.The "primary" antiphospholipid syndrome: major clinical and serological features. Medicine (Baltimore) 1989;68:366e74.

[92] Vianna JL, Khamashta MA, Ordi-Ros J, et al. Comparison of the primary and secondary antiphospholipid syndrome: a European Multicenter Study of 114 patients. Am J Med 1994;96:3e9.

[93] Stein PD, Hull RD, Matta F, et al. Incidence of thrombocytopenia in hospitalized patients with venous thromboembolism. Am J Med 2009;122: 919e30.

[94] Brick W, Burgess R, Faguet GB. Dysfibrinogenemia. WebMD. Available at: www.webmd.com. Accessed March 19, 2010.

[95] Shively BK. Deep venous thrombosis prophylaxis in patients with heart disease. Curr Cardiol Rep 2001;3:56e62.

[96] Jafri SM, Ozawa T, Mammen E, et al. Platelet function, thrombin and fibrinolytic activity in patients with heart failure. Eur Heart J 1993;14:205e12.

[97] Dries DL, Rosenberg YD, Waclawiw MA, et al. Ejection fraction and risk of thromboembolic events in patients with systolic dysfunction and sinus rhythm: evidence for gender differences in the studies of left ventricular dysfunction trials. J Am Coll Cardiol 1997;29:1074e80.

[98] Kyrle PA, Korninger C, Gossinger H, et al. Prevention of arterial and pulmonary embolism by oral anticoagulants in patients with dilated cardiomyopathy. Thromb Haemost 1985;54:521e3.

[99] Nordstro"m M, Lindblad B, Bergqvist D, et al. A prospective study of the incidence of deep-vein thrombosis within a defined urban population. J Intern Med 1992;232:155e60.

[100] Segal JP, Harvey WP, Gurel T. Diagnosis and treatment of primary myocardial disease. Circulation 1965;32:837e44.

[101] Roberts WC, Siegel RJ, McManus BM. Idiopathic dilated cardiomyopathy: analysis of 152 necropsy patients. Am J Cardiol 1987;60:1340e55.

[102] Beemath A, Stein PD, Skaf E, et al. Risk of venous thromboembolism in patients hospitalized with heart failure. Am J Cardiol 2006;98:793e5.

[103] Howell MD, Geraci JM, Knowlton AA. Congestive heart failure and outpatient risk of venous thromboembolism: a retrospective, case-control study. J Clin Epidemiol 2001;54:810e8166. 
[104] Beemath A, Skaf E, Stein PD. Pulmonary embolism as a cause of death in adults who died with heart failure. Am J Cardiol 2006;98:1073e5.

[105] Attems J, Arbes S, Bohm G, et al. The clinical diagnostic accuracy rate regarding the immediate cause of death in a hospitalized geriatric population; an autopsy study of 1594 patients. Wien Med Wochenschr 2004;154:159e62.

[106] Hsu DT, Addonizio LJ, Hordof AJ, Gersony WM. Acute pulmonary embolism in pediatric patients awaiting heart transplantation. J Am Coll Cardiol 1991;17:1621-5.

[107] Cohen AT, Tapson VF, Bergmann JF, et al. Venous thromboembolism risk and prophylaxis in the acute hospital care setting (ENDORSE study): a multinational cross-sectional study. Lancet 2008;371: 387-94.

[108] Mispelaere D, Glerant JC, Audebert M, et al. Pulmonary embolism and sibilant types of chronic obstructive pulmonary disease decompensations. Rev Mal Respir 2002;19:415e23.

[109] Tillie-Leblond I, Marquette $\mathrm{CH}$, Perez T, et al. Pulmonary embolism in patients with unexplained exacerbation of chronic obstructive pulmonary disease: prevalence and risk factors. Ann Intern Med 2006;144:390e6.

[110] Stein PD, Beemath A, Meyers FA, et al. Pulmonary embolism and deep venous thrombosis in patients hospitalized with chronic obstructive pulmonary disease. J Cardiovasc Med 2007;8:253e7.

[111] Neuhaus A, Bentz RR, Weg JG. Pulmonary embolism in respiratory failure. Chest 1978;73(4):460 -5.

[112] Schonhofer B, Kohler D. Prevalence of deep-vein thrombosis of the leg in patients with acute exacerbation of Chronic Obstructive Pulmonary Disease. Respiration 1998;65:173- 7.

[113] Gunduz S, Ogur E, Mohur H, et al: Deep vein thrombosis in spinal cord injured patients. Paraplegia 31:606410, 1993

[114] Hull R Venous thromboembolism in spinal cord injury patients Chest 102:658-662, 1992

[115] Merli GJ: Management of deep vein thrombosis in spinal cord injury. Chest 102652657, 1992

[116] Myllynen P, Kammonen M, Rokkanen P, et al: Deep venous thrombosis and pulmonary embolism in patients with acute spinal cord injury: A comparison with non-paralyzed patients immobilized due to spinal fractures. J Trauma 25:541-543, 1985

[117] Prasad DK, Banerjee AK, Howard H Incidence of deep vein thrombosis and the effect of the pneumatic compression if the calf in elderly hemiplegics. Age Aging 11:424, 1982

[118] Waring WP, Karunas RS: Acute spinal cord injuries and the incidence of clinically occurring thromboembolic disease. Paraplegia 29:8-16, 1991

[119] Yao JST Deep vein thrombosis in spinal cord-injured patients. Evaluation and assessment. Chest 102:645-648, 1992

[120] Harvey RL. Prevention of venous thromboembolism after stroke. Topics Stroke Rehab 2003;10:61e9.

[121] Skaf E, Stein PD, Beemath A, et al. Venous thromboembolism in patients with ischemic and hemorrhagic stroke. Am J Cardiol 2005;96:1731e3. 
[122] Skaf E, Stein PD, Beemath A, et al. Fatal pulmonary embolism and stroke. Am J Cardiol 2006;97:1776e7.

[123] Dismuke SE, VanderZwaag R. Accuracy and epidemiological implications of the death certificate diagnosis of pulmonary embolism. J Chronic Dis 1984;37:67e73.

[124] Heit JA, Silverstein MD, Mohr DN, Petterson TM, O'Fallon WM, Melton 3rd LJ. Risk factors for deep vein thrombosis and pulmonary embolism: a populationbased case-control study. Arch Intern Med 2000;160(6):809-15.

[125] Spencer FA, Lessard D, Emery C, Reed G, Goldberg RJ. Venous thromboembolism in the outpatient setting. Arch Intern Med 2007;167(14):1471-5.

[126] Levitan N, Dowlati A, Remick SC, Tahsildar HI, Sivinski LD, Beyth R, et al. Rates ofinitial and recurrent thromboembolic disease among patients with malignancy versus those without malignancy. Risk analysis using Medicare claims data. Medicine (Baltimore) 1999;78(5):285-91.

[127] Khorana AA, Francis CW, Culakova E, Kuderer NM, Lyman GH. Frequency, risk factors, and trends for venous thromboembolism among hospitalized cancer patients. Cancer 2007;110(10):2339-46.

[128] Stein PD, Beemath A, Meyers FA, et al. Incidence of venous thromboembolism in patients hospitalized with cancer. Am J Med 2006;119:60-8.

[129] Khorana AA, Francis CW, Culakova E, et al. Thromboembolism in hospitalized neutropenic cancer patients. J Clin Oncol 2006;24:484-90.

[130] Sallah S, Wan JY, Nguyen NP. Venous thrombosis in patients with solid tumors: determination of frequency and characteristics. Thromb Haemost 2002;87:575-9.

[131] Levitan N, Dowlati A, Remick SC, et al. Rates of initial and recurrent thromboembolic disease among patients with malignancy versus those without malignancy. Risk analysis using Medicare claims data. Medicine (Baltimore) 1999;78:285-91.

[132] Stein PD, Beemath A, Meyers FA, et al. Incidence of venous thromboembolism in patients hospitalized with cancer. Am J Med 2006;119:60-8.

[133] Chew HK, Wun T, Harvey D, et al. Incidence of venous thromboembolism and its effect on survival among patients with common cancers. Arch Intern Med 2006;166:458-64.

[134] Numico G, Garrone O, Dongiovanni V, et al. Prospective evaluation of major vascular events in patients with nonsmall cell lung carcinoma treated with cisplatin and gemcitabine. Cancer 2005;103:994-9.

[135] Weijl NI, Rutten MF, Zwinderman AH, et al. Thromboembolic events during chemotherapy for germ cell cancer: a cohort study and review of the literature. J Clin Oncol 2000;18:2169-78.

[136] White RH, Chew HK, Zhou H, et al. Incidence of venous thromboembolism in the year before the diagnosis of cancer in 528,693 adults. Arch Intern Med 2005;165:1782-7.

[137] Blom JW, Doggen CJ, Osanto S, et al. Malignancies, prothrombotic mutations, and the risk of venous thrombosis. JAMA 2005;293:715-22.

[138] Sallah S, Wan JY, Nguyen NP. Venous thrombosis in patients with solid tumors: determination of frequency and characteristics. Thromb Haemost 2002;87:575-9.

[139] Khorana AA, Francis CW, Culakova E, et al. Thromboembolism in hospitalized neutropenic cancer patients. J Clin Oncol 2006;24:484-90.

[140] Rodriguez AO, Wun T, Chew $\mathrm{H}$, et al. Venous thromboembolism in ovarian cancer. Gynecol Oncol 2007;105:784-90. 
[141] Tateo S, Mereu L, Salamano S, et al. Ovarian cancer and venous thromboembolic risk. Gynecol Oncol 2005;99:119-25.

[142] Chew HK, Wun T, Harvey DJ, et al. Incidence of venous thromboembolism and the impact on survival in breast cancer patients. J Clin Oncol 2007;25:70-6.

[143] Chew HK, Davies AM,Wun T, et al. The incidence of venous thromboembolism among patients with primary lung cancer. J Thromb Haemost 2008;6:601-8.

[144] Alcalay A, Wun T, Khatri V, et al. Venous thromboembolism in patients with colorectal cancer: incidence and effect on survival. J Clin Oncol 2006;24:1112-8.

[145] Mandala M, Reni M, Cascinu S, et al. Venous thromboembolism predicts poor prognosis in irresectable pancreatic cancer patients. Ann Oncol 2007;18:1660-5.

[146] Chew HK, Wun T, Harvey D, et al. Incidence of venous thromboembolism and its effect on survival among patients with common cancers. Arch Intern Med 2006;166:458-64.

[147] Heit JA, Silverstein MD, Mohr DN, et al. Risk factors for deep vein thrombosis and pulmonary embolism: a populationbased case-control study. Arch Intern Med 2000;160:809-15.

[148] Pritchard KI, Paterson AH, Paul NA, et al. Increased thromboembolic complications with concurrent tamoxifen and chemotherapy in a randomized trial of adjuvant therapy for women with breast cancer. National Cancer Institute of Canada Clinical Trials Group Breast Cancer Site Group. J Clin Oncol 1996;14:2731-7.

[149] Fisher B, Dignam J, Wolmark N, et al. Tamoxifen and chemotherapy for lymph nodenegative, estrogen receptor-positive breast cancer. J Natl Cancer Inst 1997;89:167382.

[150] Deitcher SR, Gomes MP. The risk of venous thromboembolic disease associated with adjuvant hormone therapy for breast carcinoma: a systematic review. Cancer 2004;101:439-49.

[151] Agnelli G, Caprini JA. The prophylaxis of venous thrombosis in patients with cancer undergoing major abdominal surgery: emerging options. J Surg Oncol 2007;96:26572.

[152] Verso M, Agnelli G. Venous thromboembolism associated with long-term use of central venous catheters in cancer patients. J Clin Oncol 2003;21:3665-75.

[153] Khorana AA, Francis CW, Culakova E, et al. Risk factors for chemotherapy-associated venous thromboembolism in a prospective observational study. Cancer 2005;104:2822-9.

[154] Edgington TS, Mackman N, Brand K, et al. The structural biology of expression and function of tissue factor. Thromb Haemost 1991;66:67-79.

[155] Nemerson Y. Tissue factor and hemostasis. Blood 1988;71:1-8.

[156] Nemerson Y. Tissue factor: then and now. Thromb Haemost 1995;74:180-4.

[157] Khorana AA, Ahrendt SA, Ryan CK, et al. Tissue factor expression, angiogenesis, and thrombosis in pancreatic cancer. Clin Cancer Res 2007;13:2870-5.

[158] Stein PD, Beemath A, Meyers FA, et al. Incidence of venous thromboembolism in patients hospitalized with cancer. Am J Med 2006;119:60e8.

[159] Stein PD, Beemath A, Meyers FA, et al. Pulmonary embolism as a cause of death in patients who died with cancer. Am J Med 2006;119:163e5.

[160] Stein PD, Hull RD, Kayali F, et al. Venous thromboembolism in pregnancy: 21 year trends. Am J Med 2004;117:121e5. 
[161] Anonymous. Oral contraception and thromboembolic disease. J R Coll Gen Pract 1967;13: 267e79.

[162] Ginsberg JS, Brill-Edwards P, Burrows RF, Bona R, Prandoni P, Buller HR, et al. Venous thrombosis during pregnancy: leg and trimester of presentation. Thromb Haemost 1992;67:519- 20

[163] Ikard RW, Ueland K, Folse R. Lower limb venous dynamics in pregnant women. Surg Gynecol Obstet 1971;132:483- 8.

[164] Macklon NC, Greer IA, Bowman AW. An ultrasound study of gestational and postural changes in the deep venous system of the leg in pregnancy. Br J Obstet Gynaecol 1997;104:191-7.

[165] Metcalfe J, Ueland K. Maternal cardiovascular adjustments to pregnancy. Prog Cardiovasc Dis 1974;16:363-74.

[166] Kerr MG, Scott DB, Samuel E. Studies of the inferior vena cava in late pregnancy. Br Med J 1964;1:532- 3.

[167] Cockett FB, Thomas ML. The iliac compression syndrome. Br J Surg 1965;52:816- 21.

[168] Hull RD, Raskob GE, Carter CJ. Serial impedance plethysmography in pregnant patients with clinically suspected deep vein thrombosis. Ann Intern Med 1990;112:663- 7.

[169] Rutherford SE, Phelan JP. Thromboembolic disease in pregnancy. Clin Perinatol 1986;13:719- 39.

[170] Stirling Y, Woolf L, North WR, Seghatchian MJ, Meade TW. Haemostasis in normal pregnancy. Thromb Haemost 1984;52:176-82.

[171] Woodhams BJ, Candotti G, Shaw R, Kernoff PB. Changes in coagulation and fibrinolysis during pregnancy: evidence of activation of coagulation preceding spontaneous abortion. Thromb Res 1989;55:99- 107.

[172] Bonnar J. Blood coagulation and fibrinolysis in obstetrics. Clin Hematol 1973;12:58 63.

[173] Comp PC, Thurnau GR, Welsh J, Esmon CT. Functional and immunologic protein S levels are decreased during pregnancy. Blood 1986;68:881- 5.

[174] Clark P, Brennand J, Conkie JA, McCall F, Greer IA, Walker ID. Activated protein C sensitivity, protein $C$, protein $S$, and coagulation in normal pregnancy. Thromb Haemost 1998;79:1166- 70.

[175] Wright JG, Cooper P, Astedt B, Lecander I, Wilde JT, Preston FE, et al. Fibrinolysis during normal human pregnancy: complex interrelationships between plasma levels of tissue plasminogen activator and inhibitors and the euglobulin clot lysis time. Br J Haematol 1988; 69:253- 8.

[176] Bremme K, Ostlund E, Almqvist I, Heinonen K, Blomback M. Enhanced thrombin generation and fibrinolytic activity in normal pregnancy and the puerperium. Obstet Gynecol 1992;80:132- 7.

[177] Kruithof EK, Tran-Thang C, Gudinchet A, Hauert J, Nicoloso G, Genton C, et al. Fibrinolysis in pregnancy: a study of plasminogen activator inhibitors. Blood 1987;69:460-6.

[178] McColl MD, Ramsay JI, Tait RD, Walker ID, McCall F, Conkie JA, et al. Risk factors for pregnancy associated venous thromboembolism. Thromb Haemost 1997;78:1183-8. 
[179] Geerts WH, Bergqvist D, Pineo GF, et al. Preventive of venous thromboembolism. American College of Chest physicians evidence-based clinical practice guidelines (8th edition). Chest 2008;133: 381Se453S.

[180] Kroger K, Schelo C, Gocke C, et al. Colour Doppler sonographic diagnosis of upper limb venous thromboses. Clin Sci 1998;94:657e61.

[181] Dollery CM, Sullivan ID, Bauraind O, et al. Thrombosis and embolism in long-term central venous access for parenteral nutrition. Lancet 1994;344: 1043e5.

[182] Mustafa S, Stein PD, Patel KC, et al. Upper extremity deep venous thrombosis. Chest 2003; 163:1213e9.

[183] Hingorani A, Ascher E, Lorenson E, et al. Upper extremity deep venous thrombosis and its impact on morbidity and mortality rates in a hospitalbased population. J Vasc Surg 1997;26:853e60.

[184] Monreal M, Lafoz E, Ruiz J, et al. Upperextremity deep venous thrombosis and pulmonary embolism. A prospective study. Chest 1991;99:280e3.

[185] Horattas MC, Wright DJ, Fenton AH, et al. Changing concepts of deep venous thrombosis of the upper extremityereport of a series and review of the literature. Surgery 1988;104:561e7.

[186] Joffe HV, Kucher N, Tapson VF, et al. Upper-extremity deep vein thrombosis: a prospective registry of 592 patients. Circulation 2004;110:1605e11.

[187] Broviac JW, Cole JJ, Scribner BH. A silicone rubber atrial catheter for prolonged parenteral alimentation. Surg Gynecol Obstet 1973; 136:602- 606.

[188] Hickman RO, Buckner CD, Clift RA, Sanders JE, Stewart P, Thomas ED. A modified right atrial catheter for access to the venous system in marrow trans-plant recipients. Surg Gynecol Obstet 1979; 148:871- 875.

[189] Foley MJ. Radiologic placement of long-term central venous peripheral access system ports (PAS Port): results in 150 patients. J Vasc Interv Radiol1995; 6:255-262.

[190] Rubenstein EB, Fender A, Rolston KV, et al. Vascular access by physician as-sistants: evaluation of an implantable peripheral port system in cancer patients. J Clin Oncol 1995; 13:1513-1519.

[191] Shetty PC, Mody MK, Kastan DJ, et al. Outcome of 350 implanted chest ports placed by interventional radiologists. J Vasc Interv Radiol 1997; 8:991-995.

[192] Schwarz RE, Groeger JS, Coit DG. Subcutaneously implanted central venous access devices in cancer patients: a prospective analysis. Cancer 1997; 79: 1635-1640.

[193] Struk DW, Bennett JD, Kozak RI. Insertion of subcutaneous central venous infusion ports by interventional radiologists. Can Assoc Radiol J 1995; 46:32-36.

[194] Hata Y, Morita S, Morita Y, et al. Peripheral insertion of a central venous access device under fluoroscopic guidance using a peripherally accessed system (PAS) port in the forearm. Cardiovasc Intervent Radiol 1998; 21:230 -233.

[195] Deppe G, Kahn ML, Malviya VK, Malone JM, Christensen CW. Experience with the P.A.S.-Port venous access device in patients with gynecologic malignancies. Gynecol Oncol 1996; 62:340 -343.

[196] Monreal M, Lafoz E, Ruiz J, Valls R, Alastrue A. Upper extremity deep venous thrombosis and pulmonary embolism; a prospective study. Chest 1991;99:280-3.

[197] Saleh T, Matta F, Yaekoub AY, et al. Risk of venous thromboembolism with inflammatory bowel disease. Clin Appl Thromb Hemost 2010. [Epub ahead of print]. 
[198] Saleh T, Matta F, Alali F, et al. Liver disease and risk of venous thromboembolism. Submitted for publication.

[199] Søgaard KK, Horva'th-Puho' E, Grønbaek H, et al. Risk of venous thromboembolism in patients with liver disease: a nationwide population-based case-control study. Am J Gastroenterol 2009;104: 96e101.

[200] Northup PG, McMahon MM, Ruhl AP, et al. Coagulopathy does not fully protect hospitalized cirrhosis patients from peripheral venous thromboembolism. Am J Gastroenterol 2006;101:1524e8.

[201] Tripodi A, Primignani M, Chantarangkul V, et al. An imbalance of pro- vs anticoagulation factors in plasma from patients with cirrhosis. Gastroenterology 2009;137:2105e11.

[202] Danescu L, Badshah A, Danescu SC, et al. Venous thromboembolism in patients hospitalized with thyroid dysfunction. Clin Appl Thromb Hemost 2009;15:676e80.

[203] Seriolo B, Accardo S, Garnero A, et al. Anticardiolipin antibodies, free protein S levels and thrombosis: a survey in a selected population of rheumatoid arthritis patients. Rheumatology 1999; 38:675e8.

[204] McEntegart A, Capell HA, Creran D, et al. Cardiovascular risk factors, including thrombotic variables, in a population with rheumatoid arthritis. Rheumatology 2001;40:640e4.

[205] Matta F, Singala R, Yaekoub AY, et al. Risk of venous thromboembolism with rheumatoid arthritis. Thromb Haemost 2009;101:134e8.

[206] Stein PD, Goldman J, Matta F, et al. Diabetes mellitus and risk of venous thromboembolism. Am J Med Sic 2009;337:259e64.

[207] Matta F, Yaekoub AY, Stein PD. Human immunodeficiency virus infection and risk of venous thromboembolism. Am J Med Sci 2008;336:402e6.

[208] Kayali F, Najjar R, Aswad F, et al. Venous thromboembolism in patients hospitalized with nephrotic syndrome. Am J Med 2008;121:226e30.

[209] Stein PD, Beemath A, Meyers FA, et al. Deep venous thrombosis and pulmonary embolism in patients hospitalized with sickle cell disease. Am J Med 2006;119:897e901.

[210] Navarro S, Ricart JM, Medina P, et al. Activated protein C levels in Behc, et's disease and risk of venous thrombosis. Br J Haematol 2004;126:550e6.

[211] Ray JG, Burows RF, Ginsberg JS, et al. Paroxysmal nocturnal hemoglobinuria and the risk of venous thrombosis: review and recommendations for management of the pregnant and nonpregnant patient. Haemostasis 2000;30:103e17.

[212] Fischer MD, Hopewell PC. Recurrent pulmonary emboli and Buerger's disease. West J Med 1981; 135:238e41.

[213] Osterud B (1998) Tissue factor expression by monocytes: regulation and pathophysiological roles. Blood Coagul Fibrinolysis 9[Suppl 1]:S9-14

[214] Osterud B, Rapaport SI (1977) Activation of factor IX by the reaction product of tissue factor and factor VII: additional pathway for initiating blood coagulation. Proc Natl Acad Sci USA 74:5260-5264

[215] Esmon CT (2001) Role of coagulation inhibitors in inflammation. Thromb Haemost 86:51-56 
[216] Schaub RG, Simmons CA, Koets MH, Romano PJ, Stewart GJ (1984) Early events in the formation of a venous thrombus following local trauma and stasis. Lab Invest 51:218-224

[217] Yang J, Furie BC, Furie B (1999) The biology of P-selectin glycoprotein ligand-1: its role as a selectin counterreceptor in leukocyte-endothelial and leukocyte-platelet interaction. Thromb Haemost 81:1-7

[218] Coughlan AF, Hau H, Dunlop LC, Berndt MC, Hancock WW (1994) P-selectin and platelet-activating factor mediate initial endotoxin- induced neutropenia. J Exp Med 179:329-334

[219] Lim YC, Snapp K, Kansas GS, Camphausen R, Ding H, Luscinskas FW (1998) Important contributions of P-selectin glycoprotein ligand-1-mediated secondary capture to human monocyte adhesion to P-selectin, E-selectin, and TNF-alphaactivated endothelium under flow in vitro. J Immunol 161:2501-2508

[220] Ramasamy S, Lipke DW, McClain CJ, Hennig B (1995) Tumor necrosis factor reduces proteoglycan synthesis in cultured endothelial cells. J Cell Physiol 162:119-126

[221] Klein NJ, Shennan GI, Heyderman RS, Levin M (1992) Alteration in glycosaminoglycan metabolism and surface charge on human umbilical vein endothelial cells induced by cytokines, endotoxin and neutrophils. J Cell Sci 102[Pt 4]:821-832

[222] Conway EM, Rosenberg RD (1988) Tumor necrosis factor suppresses transcription of the thrombomodulin gene in endothelial cells. Mol Cell Biol 8:5588-5592

[223] Murugesan G, Rani MR, Ransohoff RM, Marchant RE, Kottke-Marchant K (2000) Endothelial cell expression of monocyte chemotactic protein-1, tissue factor, and thrombomodulin on hydrophilic plasma polymers. J Biomed Mater Res 49:396-408

[224] Moore KL, Andreoli SP, Esmon NL, Esmon CT, Bang NU (1987) Endotoxin enhances tissue factor and suppresses thrombomodulin expression of human vascular endothelium in vitro. J Clin Invest 79:124-130 


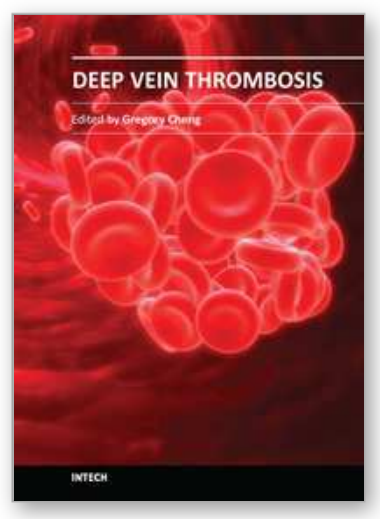

\author{
Deep Vein Thrombosis \\ Edited by Dr. Gregory Cheng
}

ISBN 978-953-51-0225-0

Hard cover, 184 pages

Publisher InTech

Published online 07, March, 2012

Published in print edition March, 2012

This book provides a comprehensive review of deep vein thrombosis. There are chapters on risk factors for DVT, post thrombotic syndrome and its management, vena cava malformation as a new etiological factor and thrombosis in the upper limbs. DVT is usually seen in patients undergoing major surgeries. The guidelines for thrombo-prophylaxis in orthopaedic patients, radical pelvic surgeries, laparoscopic operations and risks versus benefits in regions with a low prevalence of DVT are thoroughly addressed. Cancer and its treatment are recognized risk factors for VTE and extended prophylaxis in ambulatory cancer patients is reviewed. The role of imaging and endovascular therapies in acute DVT, hypercoagulabilty in liver diseases and the challenges in developing countries are discussed.

\title{
How to reference
}

In order to correctly reference this scholarly work, feel free to copy and paste the following:

Mustafa Sirlak, Mustafa Bahadir Inan, Demir Cetintas and Evren Ozcinar (2012). Risk Factors of Deep Vein Thrombosis, Deep Vein Thrombosis, Dr. Gregory Cheng (Ed.), ISBN: 978-953-51-0225-0, InTech, Available from: http://www.intechopen.com/books/deep-vein-thrombosis/risk-factors-of-deep-vein-thrombosis

\section{INTECH}

open science | open minds

\section{InTech Europe}

University Campus STeP Ri

Slavka Krautzeka 83/A

51000 Rijeka, Croatia

Phone: +385 (51) 770447

Fax: +385 (51) 686166

www.intechopen.com

\section{InTech China}

Unit 405, Office Block, Hotel Equatorial Shanghai

No.65, Yan An Road (West), Shanghai, 200040, China

中国上海市延安西路65号上海国际贵都大饭店办公楼 405 单元

Phone: +86-21-62489820

Fax: $+86-21-62489821$ 
(C) 2012 The Author(s). Licensee IntechOpen. This is an open access article distributed under the terms of the Creative Commons Attribution 3.0 License, which permits unrestricted use, distribution, and reproduction in any medium, provided the original work is properly cited. 